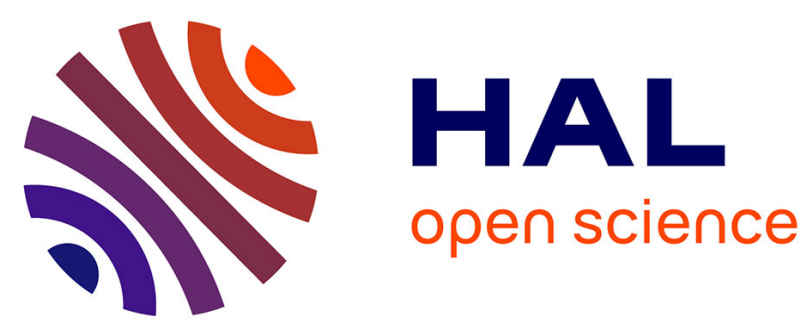

\title{
Perceived Legitimacy of Collective Punishment as a Function of Democratic versus Non-Democratic Group Structure
}

Juan M. Falomir-Pichastor, Christian Staerklé, Marie-Aude Depuiset, Fabrizio Butera

\section{To cite this version:}

Juan M. Falomir-Pichastor, Christian Staerklé, Marie-Aude Depuiset, Fabrizio Butera. Perceived Legitimacy of Collective Punishment as a Function of Democratic versus Non-Democratic Group Structure. Group Processes and Intergroup Relations, 2007, 10 (4), pp.565-579. 10.1177/1368430207081543 . hal-00571668

\section{HAL Id: hal-00571668 https://hal.science/hal-00571668}

Submitted on 1 Mar 2011

HAL is a multi-disciplinary open access archive for the deposit and dissemination of scientific research documents, whether they are published or not. The documents may come from teaching and research institutions in France or abroad, or from public or private research centers.
L'archive ouverte pluridisciplinaire HAL, est destinée au dépôt et à la diffusion de documents scientifiques de niveau recherche, publiés ou non, émanant des établissements d'enseignement et de recherche français ou étrangers, des laboratoires publics ou privés. 


\title{
Perceived Legitimacy of Collective Punishment as a Function of Democratic versus Non-Democratic Group Structure
}

\author{
Juan M. Falomir-Pichastor and Christian Staerklé \\ University of Geneva \\ Marie-Aude Depuiset and Fabrizio Butera \\ Pierre Mendès France University, Grenoble
}

\begin{abstract}
The present research tested the hypothesis that the political structure of groups moderates the perceived legitimacy of collective punishment. Participants read scenarios of fictitious summer camps in which unidentified members of one group aggressed members of another group. The political structure of both the offender and the victim groups was described as either egalitarian or hierarchical (defined with democratic or non-democratic decision-making procedures). Perceived legitimacy of collective punishment directed against all members of the offender group was assessed by measuring the acceptability of sanctions administered by an authority and of revenge actions inflicted by members of the victim group. Results showed that collective punishment was evaluated as less legitimate when the offender group was egalitarian and the victim group was hierarchical. Supplementary analyses showed that this effect was mediated by the higher value attributed to members of the offender egalitarian group when the victim group was hierarchical.
\end{abstract}

KEYWORDS aggression legitimacy, collective punishment, decision-making procedures, democracy, group value

ON May 12, 1996, Madeleine Albright, US Ambassador to the UN and future U.S. Secretary of State, was asked on CBS's 60 Minutes whether the death of half a million Iraqi children resulting from the UN sanctions was a price worth paying. Albright replied: 'I think this is a very hard choice. But the price, we think the price is worth it' (cf. Herman, 2001). This quote illustrates a phenomenon that up to now has not been directly investigated by social psychologists: the perceived legitimacy of collective punishment.

\section{Author's note}

Address correspondence to Juan M. FalomirPichastor or Christian Staerklé, Université de Genève, FPSE, Psychologie Sociale, 40 bd. du Pont d'Arve, CH-1205 Geneva, Switzerland [email: Juan.Falomir@pse.unige.ch or Christian.Staerkle@pse.unige.ch] 


\section{Collective punishment}

We refer to collective punishment as a negative or harmful treatment that authorities or outgroups inflict collectively upon an entire social group, in reaction to an offense against a formal or informal rule committed by one or more group members. Examples of collective punishment abound in social life (see Heckathorn, 1988). In many traditional societies, for example, the whole family was held accountable for the crimes committed by family members. In modern societies, collective punishment is observed in institutions such as schools, detention facilities or the army, where an entire unit of pupils, inmates or soldiers may be punished for the offences of a few. By adopting international sanctions in reaction to misdeeds of their political leaders, governments punish entire nations, and thereby accept massive civilian suffering.

These examples raise the question of the legitimacy of the sanction of innocent individuals, central in the analysis of attitudes toward collective punishment. Collective punishment may be intentionally directed at group members who are not responsible for the wrongdoing of one of its members (e.g. intergroup aggression), or inflicted unintentionally upon them as a result of what is usually called 'inevitable collateral damage'. In both cases, however, the punisher is well aware and accepts that presumed innocents will be punished. Consequently, collective punishment is at odds with the principle of individual responsibility which lies at the heart of modern conceptions of the criminal justice system (Hart, 1968), that is, with the common perception that sanctions are fair when they are inflicted upon guilty persons and unfair when they punish innocents (Hafer \& Bègue, 2005; Piaget, 1932; Vidmar \& Miller, 1980). In other words, attributed responsibility which is required to inflict a legitimate punishment upon an individual offender is absent when a social group is sanctioned for the wrongdoing of one or several of its members.

This lack of accountability raises the question of the factors that make collective punishment acceptable. In the literature on retributive justice, two major goals of punishment have been described which presumably also apply to collective punishment (Darley \& Pittman, 2003). First, if members of the offender group are viewed as potential future offenders, collective punishment may be perceived as a legitimate means for deterrence and prevention. Collective punishment becomes a technique of social control, since the sanctioned group is expected to reinforce the monitoring of the behavior of its members in order to avoid future sanctions. Collective punishment keeps deviant members in check and thereby promotes self-regulation of groups (Heckathorn, 1988, 1990). Second, collective punishment may also be motivated by a just deserts motive in which a wrongdoing is sanctioned as a function of the gravity of the offence, with the aim of restoring justice and enforcing violated group values and norms (Carlsmith, Darley, \& Robinson, 2002; Tyler \& Boeckmann, 1997).

Among the many factors that may determine judgments of legitimacy of collective punishment, the extent to which individuals or groups violate moral values of groups is particularly important for our concern (Tyler \& Smith, 1998). By moral value of the group we refer to a set of rules and norms which define right and wrong within a group, for example by prescribing 'good' conduct of group members and respectful treatment of others. Conversely, the violation of moral values refers to 'bad' and reprehensible conduct which threatens group cohesion (Sunshine \& Tyler, 2003). Individuals who symbolize or contribute to maintain and enhance moral values of an ingroup are perceived as more deserving of valued resources than less prototypical group members (Feather, 1999; Rasinski, 1987; Wenzel, 2002, 2004). An analogous reasoning applies to the allocation of negative resources such as punishment. Individuals breaking important moral values should be seen as more deserving of punishment than other offenders (Sunshine \& Tyler, 2003). Thus, whether perceivers deem a sanction legitimate or not depends on the extent to which they consider the offence to be a violation of moral values of the group (Darley, 2002; Darley \& Pittman, 2003; Vidmar \& Miller, 1980). The breaking of group rules should lead to a motivation to assert the validity of 
group values through the punishment of rule breakers (Vidmar, 2002). Transgression severity, perceived responsibility, intentionality, and lack of remorse should reinforce punitive attitudes, since deliberate wrongdoing is seen as diagnostic of contempt for group rules (Darley, 2002; Vidmar \& Miller, 1980).

The moral value of the group provides its members with a positive identity. We therefore assume that groups which are perceived as respecting moral principles will be attributed higher social value. Conversely, groups which are perceived as violating moral principles will be attributed lower social value. Accordingly, our general contention is that the moral value of groups is a key factor in the perception of legitimacy of collective punishment. More specifically, we wish to show that collective punishment inflicted upon more valued groups is perceived as less legitimate than punishment inflicted upon less valued groups, especially when the valued group is to be sanctioned for an offence committed against a less valued group.

\section{Group value and perceived legitimacy of collective punishment}

The present research focuses on perceived legitimacy of collective punishment occurring in the context of a conflict between groups. Many factors may contribute to define the moral group value in this context. Since collective punishment is inflicted on a group rather than on an individual, group perception is likely to be an important factor in the determination of the group value and of the perceived legitimacy of collective punishment. When perceivers evaluate the legitimacy of collective punishment in an intergroup context, they are likely to rely on some stereotypic information regarding the group to be sanctioned. Characteristics of the offender group shape inferences about group members; perceived group entitativity for example increases the attribution of shared responsibility for the offender's action (Lickel, Schmader, \& Hamilton, 2003).

The central research question of the present work concerns characteristics of these groups in terms of a democratic and non-democratic group structure. We argue that democratic and non-democratic political group structure is used by perceivers as a cue to infer group members' characteristics (Allison \& Messick, 1987). While group features such as wealth and social class may also relate to group value and yield similar effects, the present experiment focuses on political group structure. Prior research has provided support for the political inference hypothesis by showing that democratic and nondemocratic groups elicit particular stereotypical images of their members (Staerklé, 2005; Staerklé, Clémence, \& Doise, 1998). Members of democratic societies are perceived as relatively more autonomous, free, orderly, peaceful and politically involved. Conversely, members of non-democratic societies are associated with psychological weakness, obedience and manipulation by their leaders. They are also more likely to be perceived as disorderly and politically passive. These results suggest that lay perceivers easily associate the system and its members, by endorsing the saying that 'the people get the government they deserve' (Staerklé et al., 1998).

An important implication of this tendency to infer individual characteristics on the basis of democratic and non-democratic group structure is that inferences give perceivers cues regarding the moral value of group members. Research has indeed shown that independence and individual autonomy are culturally more valued than obedience and collectivism, especially in Western societies (e.g. Beauvois, 2005; Lorenzi-Cioldi, 1998; Sampson, 1988). In egalitarian/democratic groups perceivers expect an absence of power relationships between members, and should therefore attribute higher moral value to group members. In hierarchical/non-democratic groups, however, group members are perceived as followers who are easily manipulated and interchangeable, and therefore less valued than 'free' individuals. Similarly, the decisionmaking procedures themselves appear to be value-laden. In line with research on procedural justice, egalitarian/democratic decision-making involving the right to 'voice' is perceived as fairer and more desirable than hierarchical/nondemocratic decision-making, because all group 
members have their say in the decision-making process (Folger, 1977; see also Thibaut \& Walker, 1975; Tyler, 1997; Tyler \& Lind, 1992).

Therefore, political group structure should give cues regarding the legitimacy of behaviors performed either by or against group members. Recent research provided evidence for this hypothesis (Falomir, Staerklé, Depuiset, \& Butera, 2005). In a fictitious summer camp unidentified members of one group aggressed members of another group, thereby ostensibly breaking camp rules. The political group structure was manipulated in a $2 \times 2$ design where the interacting groups were either egalitarian or hierarchical. Results of two experiments revealed an interaction effect showing that aggressions perpetrated by democratic groups were perceived as less illegitimate than aggressions perpetrated by nondemocratic groups, especially when the victims belonged to non-democratic groups. Indeed, because of the value attributed to egalitarian groups, aggressions against egalitarian victims seem to be strongly condemned independently of the offender group's political structure.

The present experiment, in turn, was designed to examine whether political group structure acts as a moderator of the perceived legitimacy of collective punishment inflicted on the offender group. The same procedure as in Falomir et al.'s studies was used in the present study. Because members of egalitarian democratic groups are more valued than members of hierarchical non-democratic groups, one could predict a victim and a perpetrator main effect indicating that perceived legitimacy of collective punishment of members of the offender group is lowest when this group is egalitarian and the victim group hierarchical and highest when the offender group is hierarchical and the victim group egalitarian. However, in line with findings observed in previous studies (Falomir et al., 2005) we rather expect an interaction effect. Collective punishment of members of the offender group should be less supported when they are egalitarian and the offence is committed at the expense of a hierarchical group. Thereby, egalitarian groups attacking other groups are protected from subsequent retribution unless the victim group is an equally valued egalitarian group.
This experiment also intends to contribute to the understanding of the phenomenon of collective punishment by investigating the mediating role of the moral value attributed to the members of the offender group. We reasoned that collective punishment of a democratic group is unacceptable, to the extent that it is perceived as having higher moral value than a non-democratic group. According to our main prediction, this perception should appear when egalitarian groups commit an offence against a hierarchical group, but not when they attack another egalitarian group. In line with this hypothesis, we also expect that this predicted effect is mediated by the attribution of moral value. This prediction is in line with literature showing how negative and devalued stereotypes of victim groups make aggressive and hostile behavior toward them acceptable, for example in ethnic violence (Brewer, 1999; Palmer, 1998; Petersen, 2002; Staub, 1989).

Finally, we also want to rule out that attribution of responsibility of the offence to the entire social group, rather than to individual perpetrators', accounts for the expected effect of political group structure on perceived legitimacy of collective punishment. Therefore, a measure of perceived shared responsibility of group members in the offence was also included in the questionnaire. This measure will also be used to check whether egalitarian or hierarchical offender groups are perceived as being more co-responsible for the committed offence.

\section{Method}

\section{Participants}

Participants were 182 psychology undergraduates at the University of Geneva (152 women and 21 men; 9 persons did not report their sex). Their age ranged from 18 to 67 years $(M=22.59$, $S D=5.28)$. All reported effects remained significant when controlling for the sex of participants.

\section{Procedure}

The procedure was similar to the one used in Falomir et al. (2005, Study 1). The experiment was carried out during a regular social psychology lab class, and was presented as an exercise on 
group processes. Inspired by Sherif et al.'s work (1961), participants received a booklet containing a scenario of a summer camp organized by researchers in social psychology. Respondents read that participants (adolescents) were split in two groups at the beginning of the camp, and that researchers observed how the groups spontaneously organized themselves in order to perform tasks such as village building, cooking or maintenance. Researchers concluded that two main types of group structure emerged during the camp: egalitarian and hierarchical. Concerning the egalitarian groups participants learned that: (a) the groups collectively designated a few members as responsible for the coordination of the group activities (i.e. the leaders); (b) important decisions were taken collectively in an assembly in which all group members participated; and (c) all members had equal decision power. With respect to hierarchical groups, participants were informed that: (a) some adolescents proclaimed themselves as leaders; (b) important decisions were taken by these leaders without discussion with other group members; and (c) leaders had more decision power than other members. In order to prevent perceived differences at the level of ingroup agreement or the quality of the camp experience, participants were informed that members of both kinds of groups expressed equal satisfaction with their group and with the holiday camp in general.

Participants were then informed that the present study focused on an event that raised controversy among organizers and researchers. In one of the camps, there was a 'blue' and a 'red' group, described as either egalitarian or hierarchical depending on the experimental condition. One day, the Blues protested against an unfair treatment, since they considered that the organizers gave them less food compared to the Reds. The following night, during a walk in the forest, two angry members of the Blues aggressed and stole money from two members of the Reds. Since it was dark, the victims were unable to identify the two aggressors who remained unsanctioned. Instead, collective punishment of the entire blue group was now discussed. The participants were asked to evaluate several options of collective punishment for the Blues (see below). From now on, the Blue group will be referred to as the 'offender group' (the target of collective punishment) and the Red group as the 'victim group'.

\section{Independent variables}

Participants were randomly assigned to one of the four conditions from the 2 (victim group: egalitarian vs. hierarchical) $\times 2$ (offender group: egalitarian vs. hierarchical) experimental design. The group structure was reminded three times in the booklet to make sure that participants accurately associated each group with the respective decision-making structure.

\section{Dependent variables}

All answers were given on 7-point scales $(1=n o t$ at all, and $7=$ totally).

Manipulation checks As a manipulation check, participants were asked to evaluate the extent to which the members of both the victim and the offender groups were having hierarchical relations with their leaders, namely on three items: manipulated by their leaders, independent, and subordinate. A single score was computed, both for the victim group $(M=3.81, S D=1.29$, $\alpha=.82)$ and for the offender group $(M=4.04$, $S D=1.29, \alpha=.86)$, after reversing the scores for the 'independent' item.

Legitimacy of collective punishment In order to cover different functions of punishment and thus increase the validity of the analyses, three types of collective punishment were assessed.

The first form, reparation, refers to a sanction inflicted by a superordinate authority in order to repair or compensate the harm caused by the offender group to the adverse group (as opposed to punishing the offence; Daly, 2002). Two items were used: 'To what extent the entire group to which the two perpetrators belong should be forced: (a) to restore the robbed money to the victims; and (b) to publicly apologize'.

The second form of collective punishment, expiation, has a markedly more humiliating function than reparation. Two items were used: 'To what extent the entire group to which perpetrators belong should be obliged: (a) to 
do cleaning work in the Reds' village (i.e. the victim group); and (b) to pay compensation to all members of the Red group'.

Since these two sanctions benefit all members of the victim group rather than only the victims, they are arbitrary and disproportionate with respect to the initial aggression, and incompatible with the principle of restorative justice.

Finally, the third form of collective punishment under investigation is revenge inflicted by members of the victim group against members of the offender group. Revenge is a special case of collective punishment inasmuch as it is based on an informal attempt to restore justice at the intergroup level (Elster, 1990). Three items were used: 'To what extent do you consider the following actions understandable: (a) aggressiveness in sportive competitions toward the members of the offender group; (b) to humiliate the members of the offender group; and (c) to insult the members of the offender group'.

The seven items assessing collective punishment were submitted to a principal component analysis (Varimax rotation) which extracted three factors explaining $70.06 \%$ of the variance: the first one included the three items measuring the legitimacy of revenge actions $(28.84 \%$ of variance after rotation; $M=2.36, S D=0.99, \alpha=.74$ ); the second one comprised the two items assessing the legitimacy of reparation ( $21.66 \%$ of variance; $M=5.26, S D=1.27$; inter-item correlation, $r=.40, p<.001)$; and the third one comprised the two items assessing the legitimacy of expiation (18.26\% of variance; $M=3.05, S D=1.09$; inter-item correlation, $r=.27, p<.001)$. Three scores were computed by averaging the items comprising the three factors.

These variants of collective punishment vary according to both the reacting agent (authority vs. outgroup) and the function of the punishment (Darley \& Pittman, 2003): whereas reparation is mainly related to a compensatory justice motive (i.e. compensation to the victims), expiation and revenge are mainly related to a retributive justice motive.

Perceived moral value of offender group Five characteristics attributed to members of the offender group were used to assess their moral value: moral, fair, respectful, violent and thievish. As an example, they were asked to indicate 'In their character and their relations, to what extent do the members of the 'Blue' group (the offender group) appear to be moral?' A composite score of perceived moral value of the offender group was computed by averaging the five items $(M=3.57, S D=0.93, \alpha=.80)$, after reversal of the scores for violent and thievish.

Perceived responsibility of offender group One item assessed the shared responsibility attributed to the members of the offender group: 'To what extent can partial responsibility for the aggression be attributed to all the members of the offender group?' Overall perceived shared responsibility for the offence was high $(M=5.37$, $S D=1.38)$.

\section{Results}

\section{Manipulation checks}

Scores of hierarchical perception of victim and offender groups were submitted to a 2 (victim group: egalitarian vs. hierarchical) $\times 2$ (offender group: egalitarian vs. hierarchical) $\times 2$ (target group: victim vs. perpetrator) mixed-model analysis of variance (ANOVA), performed with the last factor as a repeated measure. This analysis revealed an effect of the within-participants factor $\left(F(1,178)=4.28, p<.04, \eta^{2}=.02\right)$. Overall, the members of the offender group $(M=4.04)$ were perceived as more hierarchical than the members of the victim group $(M=3.81)$. The within-participants factor interacted with the political structure of the victim group $(F(1$, $\left.178)=105.92, p<.0001, \eta^{2}=.37\right)$, as well as with the offender group structure $(F(1,178)=52.63$, $\left.p<.001, \eta^{2}=.22\right)$. The interaction between the three factors was not significant $(F(1,178)=.34$, $p<.57)$.

With respect to the perception of the offender group, the 2 (victim group: egalitarian vs. hierarchical) $\times 2$ (offender group: egalitarian vs. hierarchical) ANOVA revealed a significant main effect of group structure $(F(1,178)=56.64$, $\left.p<.001, \eta^{2}=.24\right)$. Members of the hierarchical offender group were perceived as clearly more hierarchical (i.e. manipulated, subordinate and 
dependent) $(M=4.64)$ than members of the egalitarian offender group $(M=3.42)$, thereby confirming the effectiveness of the manipulation. The main effect of the victim group structure was also significant $(F(1,178)=18.48, p<.001$, $\left.\eta^{2}=.09\right)$. Members of the offender group were perceived as more hierarchical when the victim group was egalitarian $(M=4.39)$ rather than hierarchical $(M=3.70)$. The two-way interaction was not significant $(F(1,178)=.74, p<.40)$.

As for the victim group, the same ANOVA showed that members were perceived as more hierarchical when their group was defined as hierarchical $(M=4.59)$ rather than egalitarian $(M=3.00)(F(1,178)=112.28, p<.001$, $\left.\eta^{2}=.38\right)$, thereby confirming the effectiveness of the manipulation. The victim group was also considered more hierarchical when the offender group was egalitarian $(M=4.01)$ rather than hierarchical $(M=3.62)(F(1,178)=6.78, p<.01$, $\left.\eta^{2}=.03\right)$. The interaction was not significant $(F(1,178)=.01, p<.95)$.

In sum, political group structure markedly affected the way participants perceived the relationships within the groups: when the groups were described in hierarchical terms, its members were perceived as more manipulated, submissive and dependent, compared to egalitarian groups. Consistent with findings obtained by Falomir et al. (2005), the political structure of one group also influenced the way members of the other group were perceived. ${ }^{1}$

\section{Legitimacy of collective punishment}

The 2 (offender group: egalitarian vs. hierarchical) $\times 2$ (victim group: egalitarian vs. hierarchical) multivariate analysis of variance MANOVA performed on the three variants of collective punishment as dependent measures revealed the predicted interaction $(F(3$, $\left.175)=3.31, p<.03, \eta^{2}=.054\right)$. Means across conditions are presented in Table 1. Collective punishment received the lowest support when the offender group was egalitarian and the victim group hierarchical $(M=3.19)$. In order to test our main prediction, we performed a planned comparison $(1,-3,1,1$, in the order presented in Table 1), showing that the critical condition significantly differed from the pooled remaining three conditions $(M=3.67)$ $(t(180)=3.93, p<.001)$. The two remaining orthogonal contrasts did not significantly add

Table 1. Means of perceived legitimacy of collective punishment against the offender group as a function of the political structure of offender and victim groups

\begin{tabular}{|c|c|c|c|c|}
\hline \multirow[b]{3}{*}{ Victim group: } & \multicolumn{4}{|c|}{ Offender group } \\
\hline & \multicolumn{2}{|c|}{ Egalitarian } & \multicolumn{2}{|c|}{ Hierarchical } \\
\hline & Egalitarian & Hierarchical & Egalitarian & Hierarchical \\
\hline \multicolumn{5}{|l|}{ Reparation } \\
\hline$M$ & $5.36^{\mathrm{a}}$ & $4.83^{\mathrm{b}}$ & $5.28^{\mathrm{ab}}$ & $5.56^{\mathrm{a}}$ \\
\hline$S D$ & 1.19 & 1.46 & 1.32 & 1.02 \\
\hline \multicolumn{5}{|l|}{ Expiation } \\
\hline$M$ & $3.33^{\mathrm{a}}$ & $2.70^{\mathrm{b}}$ & $3.07^{\mathrm{ab}}$ & $3.12^{\mathrm{ab}}$ \\
\hline$S D$ & 1.04 & 1.17 & 1.06 & 1.05 \\
\hline \multicolumn{5}{|l|}{ Revenge } \\
\hline$M$ & $2.44^{\mathrm{ab}}$ & $2.12^{\mathrm{a}}$ & $2.35^{\mathrm{ab}}$ & $2.54^{\mathrm{b}}$ \\
\hline$S D$ & 0.93 & 0.98 & 0.96 & 1.10 \\
\hline \multicolumn{5}{|l|}{ Overall score } \\
\hline$M$ & $3.71^{\mathrm{a}}$ & $3.19^{b}$ & $3.56^{\mathrm{a}}$ & $3.74^{\mathrm{a}}$ \\
\hline$S D$ & 0.73 & 0.81 & 0.68 & 0.59 \\
\hline
\end{tabular}

Notes: All scales ranged from 1 not at all to 7 totally. Higher means indicate higher perceived legitimacy of collective punishment. Means not sharing subscripts differ at least at $p<.05$. Number of cases per cell from left to right: $44,45,46,47$. 
explained residual variance $(F(2,178)=0.79$, $p<.46)$. Considering the overall support across the three types of collective punishment, our hypothesis was confirmed.

More specifically (see Table 1), univariate analyses showed that the interaction between experimental factors is significant with respect to reparation $(F(1,177)=4.77, p<.03$, $\left.\eta^{2}=.026\right)$, and expiation $(F(1,177)=4.42, p<.04$, $\left.\eta^{2}=.024\right)$, and marginally significant for revenge $\left(F(1,178)=3.02, p<.09, \eta^{2}=.017\right)$. The planned comparison testing for our main hypothesis was significant for reparation $(t(179)=2.65, p<.009)$, and expiation $(t(179)=2.47, p<.02)$, and marginally significant for revenge $(t(180)=1.90$, $p<.06)$. None of the residual tests reached the conventional level of significance $(F \mathrm{~s}<0.76)$.

\section{Perceived moral value of offender group}

Means of perceived moral value across conditions are presented in Table 2. The $2 \times 2$ ANOVA revealed a significant main effect of the offender group $\left(F(1,178)=14.89, p<.001, \eta^{2}=.077\right)$ : the egal-itarian offender group was attributed higher moral value $(M=3.83)$ than the hierarchical offender group $(M=3.33)$. The analysis also revealed a significant interaction effect $(F(1,178)$ $\left.=13.33, p<.001, \eta^{2}=.070\right)$. The planned comparison testing our main prediction $(1,-3,1,1$, in the order presented in Table 2) showed that the offender egalitarian group was attributed higher moral value when the victim group was hierarchical $(M=4.14)$, compared to the pooled remaining three conditions $(M=3.39)$ $(t(180)=5.00, p<.001)$. Test of residual was not significant $(F(2,178)=2.21, p<.12)$.

\section{Perceived shared responsibility of the offender group}

The $2 \times 2$ ANOVA showed only a marginally significant main effect of the offender group structure $(F(1,176)=2.98, p<.09)$ : attributed shared responsibility tended to be lower when the group was egalitarian $(M=5.21)$ rather than hierarchical $(M=5.52)$. The interaction effect was not significant $(F(1,176)=2.03, p<.16)$. The planned comparison testing for the main prediction was not significant $(t(178)=1.08$, $p<.29)$.

\section{Mediation analyses}

Following Baron and Kenny's (1986) procedure, we performed a series of regression analyses by using the contrast relative to the predicted effect $(1,-3,1,1$, in the order presented in Table 1) as the independent variable, the three measures of collective punishment as dependent variables and attributed moral value and shared responsibility as mediators, considered separately. First, and as previously indicated, the contrast significantly predicted reparation $(\beta=-.19, p<.009)$, and expiation $(\beta=-.18$, $p<.02)$, whereas this effect was only marginally significant for revenge $(\beta=-.14, p<.06)$. Second,

Table 2. Means for attributed moral value and shared responsibility of members of the offender group as a function of the political structure of offender and victim groups

\begin{tabular}{|c|c|c|c|c|}
\hline \multirow[b]{3}{*}{ Victim group: } & \multicolumn{4}{|c|}{ Offender group } \\
\hline & \multicolumn{2}{|c|}{ Egalitarian } & \multicolumn{2}{|c|}{ Hierarchical } \\
\hline & Egalitarian & Hierarchical & Egalitarian & Hierarchical \\
\hline \multicolumn{5}{|l|}{ Moral value } \\
\hline$M$ & $3.51^{\mathrm{a}}$ & $4.14^{\mathrm{b}}$ & $3.49^{\mathrm{a}}$ & $3.17^{\mathrm{a}}$ \\
\hline$S D$ & 0.81 & 0.89 & 0.93 & 0.84 \\
\hline \multicolumn{5}{|c|}{ Shared responsibility } \\
\hline$M$ & 5.22 & 5.20 & 5.28 & 5.77 \\
\hline$S D$ & 1.30 & 1.45 & 1.16 & 0.92 \\
\hline
\end{tabular}

Notes: All scales ranged from 1 not at all to 7 totally. Higher means indicate higher moral value and shared responsibility. Means not sharing subscripts differ at least at $p<.001$. Number of cases per cell from left to right: $44,45,46,47$. 
the contrast predicted moral value $(\beta=.34$, $p<.001)$, but not shared responsibility $(\beta=-.08$, $p<.29)$. Accordingly, shared responsibility did not constitute a reliable mediator and was not considered further. Third, when both moral value and the contrast effect were included in the equation, moral value significantly predicted expiation $(\beta=-.28, p<.001)$, and reparation $(\beta=-.32, p<.001)$, but not revenge $(\beta=.04$, $p<.62)$. The effect of the contrast became nonsignificant as regards expiation $(\beta=-.08$, $p<.28$ ) (Sobel test, $z=3.03, p<.001$ ) and reparation $(\beta=-.08, p<.26(z=3.25, p<.001)$, but remained marginally significant as regards revenge $(\beta=-.15, p<.06(z=0.50, p<.62)$.

In sum, mediation analyses suggest that perceived moral value of the group acts as a mediator of the effect of political group structure on perceived legitimacy of collective punishment with respect to authority-inflicted sanctions (i.e. expiation and reparation), but does not mediate the effect on intergroup revenge. Even though shared responsibility attributed to the members of the offender group was positively related to collective punishment $(r(180)=.24, p<.001)$, this factor neither fully nor partially mediated the observed pattern of effects.

\section{Discussion}

Collective punishment has only received scant and indirect attention at best by social psychologists. It is a widely observed and fascinating phenomenon not only because it refers to many contemporary debates about the fairness of such techniques (e.g. in international relations), but also because it involves social psychological mechanisms which extend a punitive reaction to an offence committed by a group member to the entire group. Collective punishment therefore requires a justification to overcome a fundamental dilemma between reaching a desirable outcome through collective punishment and sanctioning presumably innocent group members.

The present research analysed the impact of perceptions of democratic and non-democratic groups on the perceived legitimacy of collective punishment. The main finding showed that collective punishment is the least legitimate when an offence has been committed by members of an egalitarian group at the expense of members of a hierarchical group, compared to the other three combinations of experimental groups. By eliciting the lowest level of reprehension, the condition in which egalitarian groups aggress hierarchical groups thus clearly stood out. This finding was consistent across three types of collective punishment, that is, reparation and expiation inflicted by a superordinate authority and revenge actions perpetrated by the victim group, even if the effect was only marginally significant with respect to revenge.

The key to understand this finding is the result showing that members of the egalitarian offender group were attributed higher moral value than the hierarchical offender group. Even more importantly, participants attributed higher moral value to the egalitarian offender group when the victim group was hierarchical rather than egalitarian. Thus, also in terms of perceived moral value the condition defined with an egalitarian group attacking a hierarchical group stood out. Furthermore, the findings also revealed that moral value mediated the impact of political organization on perceived legitimacy of collective punishment. The only exception to this pattern was found with respect to revenge, suggesting that perceived moral value is particularly important as a mediator of collective punishment inflicted by authorities rather than by victim groups. Even if unexpected, this finding may reflect that authority-inflicted sanctions require a stronger moral justification than spontaneous acts of revenge. Moreover, it could also be that the reversed roles of the antagonistic groups implied by revenge actions (i.e. the revenge was carried out by the victim group) yielded greater confusion in the scenario which introduced additional concerns about the legitimacy of this act in terms of the political group structure of the avenger.

Before concluding, several issues deserve our attention. One important question is whether an ingroup favoritism hypothesis derived from social identity theory (Tajfel, 1981) could also explain the observed dynamics. Indeed, it could be argued that participants perceive egalitarian 
groups as ingroups and hierarchical groups as outgroups, and therefore be motivated to prevent the ingroup from negative treatment such as collective punishment. Nevertheless, we think that the present findings are better understood in terms of a higher moral value attributed to egalitarian groups for three reasons. First, although our participants are citizens of a democratic country, there is no indication that they have perceived themselves as members of adolescent summer camp groups, which is the most salient feature in the cover story. Second, this alternative explanation would require that participants identify more with egalitarian than with hierarchical groups. However, our previous work (Falomir et al., 2005) has shown that: (a) identification with both victim and offender groups was very low; (b) the greater identification with egalitarian groups was inconsistent across victim and offender groups, as well as across studies; and (c) identification did only weakly and inconsistently mediate the effect of group structure on perceived illegitimacy of the aggression. In other words, the effect of the political structure cannot merely be reduced to a greater identification with egalitarian groups. Third, the alternative explanation also requires that participants overall feel closer to egalitarian groups than to hierarchical groups. Yet, even if egalitarianism is a valued ideal in our society, hierarchical group organizations are ubiquitous and socially valued in many instances, for example in family and work groups, school and army, or youth organizations. Accordingly, there is no reason to think that our participants necessarily feel they are members of egalitarian groups in which leaders are designated collectively and important decisions taken collectively. In sum, participants are presumably well aware of the fact that democratic societies are made up of both egalitarian and hierarchical groups. As a consequence, the higher social, ideological and moral value associated to egalitarian groups (Beauvois, 2005) seems to be a more appropriate explanation of the present findings than ingroup favoritism. However, given that categorization, ingroup identification and moral value attribution are intrinsically related processes, we readily admit that the present study cannot provide a conclusive answer to these concerns. Future research should therefore examine whether the observed findings are consistent across participants identifying with egalitarian vs. hierarchical groups.

The issue of whether the present findings are specific to collective punishment or reflect more general processes of punishment also needs to be addressed. Indeed, the main dependent measures referred to the entire offender group, without differentiating perceived legitimacy of collective and perpetrator punishment. This is a limitation of the present study, although we did address the dilemma of assigning punishment to innocents as a supplementary prediction to the main hypothesis concerning the higher value of egalitarian groups. In future studies, additional measures that orthogonally assess the punishment of individuals vs. groups, or punishing guilty vs. innocent group members, should be included in order to gain a better understanding of the motivations underlying different modalities of punishment.

Another potential explanation for our findings might be differential perceptions of shared responsibility. The results on this measure of responsibility, however, were not conclusive. The egalitarian offender group tended to be perceived as less responsible for the aggression than the hierarchical offender group, and perceived shared responsibility was positively related to perceived legitimacy of collective punishment. However, shared responsibility did not mediate the effect of political group structure on perceived legitimacy of collective punishment. One possible explanation is that opposing predictions can be made with respect to shared responsibility. On the one hand, the positively valued egalitarian offender group should be perceived as less responsible for a misdeed than the negatively valued hierarchical group, and the results showed a marginal effect in this direction. On the other hand, since members of egalitarian groups are seen as participating in group decision making, they may also be perceived as more responsible for actions performed in the name of the group (Staerklé et al., 1998). 
The conflict between these two tendencies may have worked against the emergence of a clear role for shared responsibility in our study. Furthermore, it is also possible that the one-item measure used to assess shared responsibility was not reliable. Future research should reconsider the contribution of shared responsibility in the construction of legitimacy judgments of collective punishment.

Finally, still other processes could account for our findings. It could be argued, for instance, that collective punishment against egalitarian groups was perceived as less legitimate in the observed conditions because of stereotypes associated with members of egalitarian (e.g. autonomous, independent) and hierarchical groups (e.g. submissive, dependent; see Staerklé, 2005). Political group structure may also shape perceptions of the way the group reacts to misdeeds perpetrated by some group members. The higher moral value attributed to egalitarian groups may for example lead perceivers to consider that egalitarian groups react more appropriately to offences by showing guilt, remorse and empathy toward victims. Future studies should examine whether factors such as stereotypes, perceived group entitativity (Yzerbyt, Judd, \& Corneille, 2004) and collective guilt (Branscombe, 2004) affect judgments of the legitimacy of collective punishment.

To sum up, the observed findings extend those obtained by Falomir et al. (2005) on perceived legitimacy of intergroup aggression to the realm of compensatory and retributive justice (Darley \& Pittman, 2003; Feather, 1999; Vidmar 2002). They provide further evidence for the basic assumption that the perceived value of groups, attributed namely as a function of their political structure, is a key factor in judgments of legitimacy of aggressive behavior carried out in the name of groups (Staerklé, 2005; Staerklé et al., 1998). The perceived moral value of groups drives perceptions of legitimacy of both aggressive conduct and collective punishment, an observation consistent with the idea that outgroup stereotypes become symbolic devices justifying political projects (Klein \& Licata, 2003; Reicher \& Hopkins, 2000).

\section{Social functions of collective punishment}

Given the deliberately inflicted harmful treatment on innocents, collective punishment is a severe reaction to an offence which is in need of strong justification. Two general motives for collective punishment can be identified: the deterrence motive and the just deserts motive. The deterrence motive aims to prevent future wrongdoing. Because of the characteristics of the present research (e.g. the aggression was presented as an isolated and specifically motivated act and the possibility of future camps was not evoked), it seems difficult to understand the observed findings as the consequence of such a motive. However, this motive deserves attention because collective punishment is not only a technique to dissuade individuals from violating group rules. It is also a technique fostering social control, as it implies the delegation of responsibility of preventing future wrongdoing at the level of the ingroup (Heckathorn, 1990). Thereby, ingroup members are expected to keep their potentially deviant and aggressive ingroup members in check. It is therefore a powerful technique to restore or maintain order.

With respect to the just deserts motive, two views may be consistent with the common finding of the primacy of this motive in punishments (Darley \& Pittman, 2003). On the one hand, the group should be punished because it is to some extent held accountable for the offence committed by one of its members. Here, all members of the offender group are punished, because they are considered guilty by association (Doosje, Branscombe, Spears, \& Manstead, 1998). Indeed, the positive relationship between perceived coresponsibility and collective punishment suggests that a just deserts motive underlies support for collective punishment.

On the other hand, the interpretation in terms of a just deserts motive is also consistent with the symbolic function of punishments, destined to reassert the validity of violated values: innocents are punished because the group needs to pay for the wrongdoings of one of its members. Such a retributive motivation has been evidenced in contexts involving punishment of individual offenders 
(Darley, 2002), for example concerning the legitimacy of severe punitive measures (Tyler \& Boeckmann, 1997), racial bias in punitive attitudes (Green, Staerklé, \& Sears, 2006), or the tendency to punish ingroup offenders more severely than outgroup offenders (Marques, Abrams, \& Serodio, 2001). The observed findings suggest that such a motivation may also underlie the desire to punish all members of the offender group, especially when perceived moral value of the group is low. Which are the values and rules violated in our experimental context? First, the principle of non-violence and fair treatment that should be observed in any summer camp was violated by some members of the offender group. Second, hierarchical groups may be seen as violating the values of equality and participation. Hence, participants may have accepted to punish innocents in order to symbolically reassert the status of these two values.

These various explanations suggest that justification of collective punishment can be based on two major types of motivations. First, support for collective punishment may be initially motivated by the offence perpetrated by individual group members. In this case, the difficulty of identifying them and the characteristics of the group justify the extension of the punishment to all the members, accepted as undesirable but necessary 'collateral damage' in order to do justice. Second, collective punishment may be motivated, or at least facilitated, by group attributes violating valued ideals such as equality, participation and democracy. In this case, the initial offence is a mere excuse to inflict sanctions on the devalued group. This second interpretation would imply a deliberate willingness to punish members of the offender group, admittedly innocents. Egalitarian and democratic values become, paradoxically, the basic motive to punish innocents, provided that some triggering event such as the initial aggression is present. Future research is needed in order to clarify these motives.

Our findings raise the question of whether wrongdoings committed by democratic groups are always more likely to be condoned than those committed by non-democratic groups. Our past (Falomir et al., 2005) and present research suggests that egalitarian offences are more acceptable when the victim group is hierarchical. However, severity of the punishment may also increase when the offender violates important ingroup values (Marques et al., 2001; Vidmar, 2002). Hence, it could also be expected that the motivation to punish egalitarian rather than hierarchical rule breakers should be stronger.

This contradiction may also apply to an international level of analysis, even if democracy is a complex notion that cannot be reduced to the way it was operationalized in the present research. Military interventions by democratic against non-democratic nations may be better supported if they are carried out in the name of the value of democracy. At the same time, however, democratic countries are expected to resolve conflicts in a more peaceful way than are non-democratic countries (e.g. Doyle, 1983; Healy, Hoffman, Beer, \& Bourne, 2002). Therefore, democratic military solutions may be more strongly condemned since they violate the principle of peaceful solutions to conflict. Future research is necessary to examine such paradoxes in more detail, because they are likely to be a key factor in understanding how intergroup dynamics shape attitudes toward individual and collective punishment.

\section{Notes}

1. This finding suggests that group perception is relative rather than absolute: given the aggression, group perception (both hierarchical and egalitarian) was polarized when the rival group was different rather than similar. This finding also illustrates an implicit association between egalitarian groups and peaceful solutions of conflict, on the one hand, and hierarchical groups and aggressive solutions, on the other. Indeed, the offender group was perceived as more hierarchical than the victim group, and this effect was enhanced both when the offender group was described as hierarchical (i.e. more in line with aggressive solutions) and when the victim group was egalitarian (i.e. more in line with peaceful solutions). Despite these concerns, it is worth noting that this contrast effect is symmetric within independent factors (overall interactions 
were not significant) and, therefore, it cannot account for the main interaction hypothesis. Furthermore, precautionary covariance analyses were performed and showed that these group perceptions did not affect the perceived legitimacy of collective punishment. Accordingly, these results have no impact on our understanding of the main findings.

\section{Acknowledgements}

This work was supported by the Swiss National Science Foundation and the 'Avenir' program of the Rhône-Alpes regional council (France). This article was partly written while Christian Staerklé was a visiting fellow at UCLA funded by an advanced researcher fellowship from the Swiss National Science Foundation. Part of this work was presented at the EAESP small group meeting 'War and Peace' (Geneva, 2004).

\section{References}

Allison, S. T., \& Messick, D. M. (1987). From individual inputs to group outputs, and back again. Group processes and inferences about members. In C. Hendrick (Ed.), Review of personality and social psychology (Vol. 8, pp. 11-143). Newbury Park, CA: Sage.

Baron, R. M., \& Kenny, D. A. (1986). The moderator-mediator variable distinction in social psychological research: Conceptual, strategic, and statistical considerations. Journal of Personality and Social Psychology, 51, 1173-1182.

Beauvois, J. L. (2005). Les illusions libérales, individualisme et pouvoir social: Petit traité sur des grandes illusions [Liberal illusions, individualism and social power: Little treatise on big illusions]. Grenoble: Presses Universitaires de Grenoble.

Branscombe, N. R. (2004). A social psychological process perspective on collective guilt. In N.R. Branscombe \& B. Doosje (Eds.), Collective guilt: International perspectives (pp. 320-334). Cambridge, UK: Cambridge University Press.

Brewer, M. B. (1999). The psychology of prejudice: Ingroup love or outgroup hate. Journal of Social Issues, 55, 429-444.

Carlsmith, K. M., Darley, J. M., \& Robinson, P. H. (2002). Why do we punish? Deterrence and just deserts as motives for punishment. Journal of Personality and Social Psychology, 83, 284-299.

Daly, K. (2002). Restorative justice. Punishment and Society, 4, 55-79.
Darley, J. M. (2002). Just punishments: Research on retributional justice. In M. Ross \&

D.T. Miller (Eds.), The justice motive in everyday life (pp. 314-333). Cambridge, UK: Cambridge University Press.

Darley, J. M., \& Pittman, T. S. (2003). The psychology of compensatory and retributive justice. Personality and Social Psychology Review, 7, 324-336.

Doosje, B., Branscombe, N. R., Spears, R., \& Manstead, A. S. R. (1998). Guilty by association: When one's group has a negative history. Journal of Personality and Social Psychology, 75, 872-886.

Doyle, M. (1983). Kant, liberal legacies, and foreign affairs. Philosophy and Public Affairs 12, 205-235.

Elster, J. (1990). Norms of revenge. Ethics, 100, 862-885.

Falomir, J. M., Staerklé, C., Depuiset, M.-A., \& Butera, F. (2005). Democracy justifies the means: Political group structure moderates the perceived legitimacy of intergroup aggression. Personality and Social Psychology Bulletin, 31, 1683-1695.

Feather, N. (1999). Judgments of deservingness: Studies in the psychology of justice and deservingness. Personality and Social Psychology Review, 3, 86-107.

Folger, R. (1977). Distributive and procedural justice: Combined impact of 'voice' and improvement of experienced inequity. Journal of Personality and Social Psychology, 35, 108-119.

Green, E., Staerklé, C., \& Sears, D. O. (2006). Symbolic racism and Whites' attitudes toward punitive and preventive crime policies. Law and Human Behavior, 30, 435-454.

Hafer, C. L., \& Bègue, L. (2005). Experimental research on just-world theory: Problems, developments and future challenges. Psychological Bulletin, 131, 128-167.

Hart, H. L. A. (1968). Punishment and responsibility. New York: Oxford University.

Healy, A. F., Hoffman, J. M., Beer, F. A., \& Bourne Jr., L. E. (2002). Terrorist and democrats: Individual reactions to international attacks. Political Psychology, 23, 439-467.

Heckathorn, D. D. (1988). Collective sanctions and the creation of prisoner's dilemma norms. American Journal of Sociology, 94, 535-562.

Heckathorn, D. D. (1990). Collective sanctions and compliance norms: A formal theory of groupmediated social control. American Sociological Review, 55, 366-384.

Herman, E. S. (2001). The price is worth it. Anti Imperialist league: Peace and resistance. Retrieved 
April 29, 2005, from http://www.chss.montclair. edu/english/furr/pol/wtc/hermantheprice. html

Klein, O., \& Licata, L. (2003). When group representations serve social change: The speeches of Patrice Lumumba during the decolonization of Congo. British Journal of Social Psychology, 42, 571-594.

Lickel, B., Schmader, T., \& Hamilton, D. L. (2003). A case of collective responsibility: Who else was to blame for the Columbine High School shootings? Personality and Social Psychology Bulletin, 29, 194-204.

Lorenzi-Cioldi, F. (1998). Group status and perceptions of homogeneity. European Review of Social Psychology, 9, 31-75.

Marques, J., Abrams, D., \& Serodio, R. G. (2001). Being better by being right: Subjective group dynamics and derogation of in-group deviants when generic norms are undermined. Journal of Personality and Social Psychology, 81, 436-447.

Palmer, A. (1998). Colonial and modern genocide: Explanations and categories. Ethnic and Racial Studies, 21, 89-115.

Petersen, R. (2002). Understanding ethnic violence. Cambridge, UK: Cambridge University Press.

Piaget, J. (1932). The moral judgment of the child. London : Kegan Paul.

Rasinski, K. (1987). What's fair is fair-or is it? Value differences underlying public views about social justice. Journal of Personality and Social Psychology, 53, 201-211.

Reicher, S., \& Hopkins, N. (2000). Self and nation. London: Sage.

Sampson, E. E. (1988). The debate on individualism: Indigenous psychologies of the individual and their role in personal and societal functioning. American Psychologist, 43, 15-22.

Sherif, M., Harvey, O. J., White, B. J., Hood, W. R., \& Sherif, C. W. (1961). Intergroup conflict and cooperation: The Robber's Cave Experiment. Norman. University of Oklahoma.

Staerklé, C. (2005). L'idéal démocratique perverti: Antagonismes dans les représentations du nonoccident. [The perverted ideal of democracy: Antagonism in representations of the non-West.] In M. Sanchez-Mazas \& L. Licata (Eds.), L'autre: Regards psychosociaux [The other: Psychosocial views] (pp. 117-148). Grenoble: Presses Universitaires de Grenoble.

Staerklé, C., Clémence, A., \& Doise, W. (1998). Representation of human rights across different national contexts: The role of democratic and non-democratic populations and governments. European Journal of Social Psychology, 28, 207-226.

Staub, E. (1989). The roots of evil: The origins of genocide and other group violence. New York: Cambridge University Press.

Sunshine, J., \& Tyler, T. (2003). Moral solidarity, identification with the community, and the importance of procedural justice: The police as prototypical representatives of a group's moral values. Social Psychology Quarterly, 66, 153-165.

Tajfel, H. (1981). Human groups and social categories. Cambridge, UK: Cambridge University Press.

Thibaut, J., \& Walker, L. (1975). Procedural justice. Hillsdale, NJ: Erlbaum.

Tyler, T. R. (1997). The psychology of legitimacy: A relational perspective on voluntary deference to authorities. Personality and Social Psychology Review, 1, 323-345.

Tyler, T. R., \& Boeckmann, R. (1997). Three strikes and you're out, but why?: The psychology of public support for punishing rule breakers. Law and Society Review, 3, 237-265.

Tyler, T. R., \& Lind, E. A. (1992). A relational model of authority in groups. In M. Zanna (Ed.), Advances in experimental social psychology (Vol. 25, pp. 115-292). San Diego, CA. Academic Press.

Tyler, T. R, \& Smith, H. J. (1998). Social justice and social movements. In D.T. Gilbert, S.T. Fiske, \& G. Lindzey (Eds.), The handbook of social psychology (4th ed., Vol. 2, pp. 595-629). Boston: McGraw-Hill.

Vidmar, N. (2002). Retributive justice: Its social context. In M. Ross \& D.T. Miller (Eds.), The justice motive in everyday life (pp. 291-313). Cambridge, UK: Cambridge University Press.

Vidmar, N., \& Miller, D.T. (1980). Social psychological processes underlying attitudes toward legal punishment. Law and Society Review, 14, 565-602.

Wenzel, M. (2002). What is social about justice? Inclusive identity and group values as the basis of the justice motive. Journal of Experimental Social Psychology, 38, 205-218.

Wenzel, M. (2004). A social categorization approach to distributive justice. European Review of Social Psychology, 15, 219-257.

Yzerbyt, V. Y., Judd, C. M., \& Corneille, O. (2004). The psychology of group perception: Perceived variability, entitativity, and essentialism. London: Psychology Press.

Paper received 18 October 2005; revised version accepted 24 February 2006. 


\section{Biographical notes}

JUAN M. FALOMIR-PICHASTOR is Senior Lecturer in social psychology at the University of Geneva, Switzerland. His research interests include social influence, persuasion, intergroup relations, and aggression legitimacy.

CHRISTIAN STAERKLÉ is currently a lecturer in social psychology at the University of Geneva, Switzerland. His research focuses on a political approach to social psychology, in particular concerning the role of intergroup processes in social justice attitudes.
MARIE-AUDE DEPUISET completed her PhD in social psychology at the Pierre Mendès France University at Grenoble, France. Her research interests include intergroup relations, national identity, and social discrimination.

FABRIZIO BUtera is Professor of social psychology at the University of Lausanne, Switzerland. His research focuses on social change, more specifically in the area of social learning, cooperative versus competitive conflict, minority influence, and social discrimination. 